\title{
Isochrysis galbana and Diacronema vlkianum biomass incorporation in pasta products as PUFA's source
}

\author{
Mónica Fradique ${ }^{\mathrm{a}}$, Ana Paula Batista ${ }^{\mathrm{a}, \mathrm{b}}$, M. Cristiana Nunes ${ }^{\mathrm{a}, \mathrm{d}}$, Luísa Gouveia ${ }^{\mathrm{b}}$, Narcisa M. Bandarra ${ }^{\mathrm{c}}$, \\ Anabela Raymundo ${ }^{\mathrm{a}, \mathrm{d}, *}$ \\ a Núcleo de Investigação em Engenharia Alimentar e Biotecnologia, Instituto Piaget - ISEIT de Almada, Quinta da Arreinela de Cima, 2800-305 Almada, Portugal \\ ${ }^{\mathrm{b}}$ Unidade de Bioenergia, Laboratório Nacional de Energia e Geologia (LNEG), Estrada do Paço do Lumiar, 1649-038 Lisboa, Portugal \\ ${ }^{c}$ Unidade de Valorização dos Produtos da Pesca e da Aquicultura, INRB/L-IPIMAR, Av. Brasília, 1449-005 Lisboa, Portugal \\ ${ }^{\mathrm{d}}$ CEER - Engineering Biosystems, Instituto Superior de Agronomia, Tapada da Ajuda, 1349-017 Lisboa, Portugal
}

\section{A R T I C L E I N F O}

\section{Article history:}

Received 26 October 2010

Received in revised form

20 April 2012

Accepted 9 May 2012

\section{Keywords}

Pasta

Isochrysis galbana

Diacronema vlkianum

EPA

DHA

\begin{abstract}
A B S T R A C T
Factors such as an ageing population, increased health care costs and rapid advances in science and technology are likely driving the increase interest among consumers in attaining wellness through diet, which is in turn, fuelling interest in functional foods and changing the way that people eat.

Microalgae have been largely cultured and commercialized as food and feed additives, their potential as source of high-added value compounds and their ability to positively affect human's health due to their original chemical composition, is well known. Considering pasta is a main staple food, the objective of this study was to prepare fresh spaghetti enriched with different amounts of microalgae and to compare the fatty acid profile of pastas before and after cooking, with standard semolina spaghetti.

The results show that fatty acid profile of pastas prepared with Isochrysis galbana and Diacronema vlkianum biomass incorporation, presented a high resistance to the thermal treatment applied during the cooking procedure. The increase of the amount of the algae lead to a significant increase of EPA (Eicosapentaenoic Acid) and DHA (Docosahexaenoic Acid) both in raw and cooked pastas, omega-3 fatty acids that can be obtained through seafood.
\end{abstract}

(c) 2012 Elsevier Ltd. All rights reserved.

\section{Introduction}

Pasta products such as macaroni, spaghetti, vermicelli and noodles are manufactured from durum wheat semolina (Triticum durum), known to be the best raw material suitable for pasta production due to its unique colour, flavour and cooking quality (Feillet \& Dexter, 1996). Semolina is processed by adding water, extruding the dough into the desired shape and drying it under well controlled conditions to prevent the development of cracks (Guinea, Rojo, \& Elices, 2004). In recent years, pasta has become more popular due to its low cost, convenience of transportation, long shelf life and nutritional properties, being regarded as a product with low glycaemic index (Bergman, Gualberto, \& Weber,

\footnotetext{
* Corresponding author. Núcleo de Investigação em Engenharia Alimentar e Biotecnologia, Instituto Piaget - ISEIT de Almada, Quinta da Arreinela de Cima, 2800-305 Almada, Portugal. Tel.: +351 212946274; fax: +351 212946251.

E-mail addresses: hfradique@almada.ipiaget.org (M. Fradique), pbatista@ almada.ipiaget.org (A.P. Batista), crnunes@almada.ipiaget.org (M.C. Nunes), luisa.gouveia@ineti.pt (L. Gouveia), narcisa@ipimar.pt (N.M. Bandarra), araymundo@almada.ipiaget.org (A. Raymundo).
}

1994; Bjork, Liljeberg, \& Ostman, 2000; Cubadda, 1994; Jenkins, Wolever, \& Jenkijns, 1988). Nutritionists consider that pasta is highly digestible and provides significant quantities of complex carbohydrates, protein and B vitamins. Pasta is low in sodium, lipids and it has no cholesterol producing a low-postprandial response to glucose and insulin in the blood (Cleary \& Brennan, 2006; Douglass \& Mathews, 1982; Tudorica, Kuri, \& Brennan, 2002). Pastas nutritional quality can be enhanced through the addition of nontraditional raw materials rich in fibres (Brennan, Kuri, \& Tudorica, 2003; Chillo, Laverse, Falcone, Protopapa, \& Del Nobile, 2008), vitamins and polyunsaturated fatty acids (Iafelice et al., 2008; Verardo et al., 2009). Microalgae could be an interesting alternative raw material to improve pasta nutritional profile, as already showed by the authors (Fradique et al., 2010).

Omega-3 polyunsaturated fatty acids ( $\omega 3$-PUFA), especially very long chain eicosapentaenoic acid (EPA, 20:5 $\omega 3$ ) and docosahexaenoic acid (DHA, 22:6 $\omega 3$ ), are recognised as having a number of important beneficial health effects (Horrocks \& Yeo, 1999; Shahidi \& Wanasundara, 1998). EPA and DHA are precursors in the synthesis of prostaglandins, leukotrienes, tromboxanes and resolvins, which bind to specific protein receptors and signal 
cellular physiological responses to inflammation, vasodilation, blood pressure, pain and fever, playing an important role in the prevention of cardiovascular diseases, type II diabetes, ocular diseases, arthritis and cystic fibrosis (Funk, 2001; Simopolous, 1999). w3-PUFA, especially DHA, are essential in the diet of infants in order to achieve full cognitive development potential, fact that had been claimed on the basis of reports that infants fed with breast milk (that naturally contains DHA) perform better on tests that assess neurodevelopmental outcomes, than do infants fed on formula milk that lack this fatty acid (Arteburn et al., 2007; Crawford, 2000; Ghys, Bakkere, Hornstra, \& Van der Hout, 2002; Gibson \& Makrides, 2001). EPA performs many vital functions in biological membranes and serves as a precursor of a variety of lipid regulators in cellular metabolism (Gill \& Valivety, 1997; Nettleton, 1995). These findings have led to considerable interest in developing commercial processes for EPA production (Belarbi, Molina, \& Chisti, 2000; Molina Grima, Belarbi, Acién Fernández, Robles Medina, \& Chisti, 2003).

Omega- 3 fatty acids are essential compounds that cannot be synthesized by humans and must be provided in the diet. The major dietary sources of EPA and DHA are oily fish (e.g. salmon, mackerel, sardines), fish oils, certain nuts and plant oils, whereas canola, walnut, soybean, and flaxseed oils contain $\alpha$-linolenic acid (ALA 18:3 $\omega 3$ ) (Kris-Etherton, Harris, \& Lawrence, 2003). Nowadays, the Western diet does not include enough fish oil to meet dietary recommendations for EPA and DHA, minimum of two fish servings a week (Kolanowski \& Laufenberg, 2006). This limitation can be overcome by enriching food products with sources of omega-3 PUFA (Barrow, Nolan, \& Holub, 2009). Marine fish oil is the richest source for EPA and DHA, but may not be the ideal source of $\omega 3$ PUFA due to its high susceptibility towards oxidation and consequent off-flavours, as well as geographical and seasonal variations in quality and scarcity (Belarbi et al., 2000; Liu \& Lin, 2001). In this way, much effort is being devoted to developing a commercially feasible technology to produce EPA and DHA directly from microalgae which are the primary producers of these $\omega 3$ PUFA in the food chain (Barclay, Meager, \& Abril, 1994; Lebeau \& Robert, 2003; Molina Grima et al., 2003; Pulz \& Gross, 2004).

Isochrysis galbana (Ig) and Diacronema vlkianum (Dv) are two marine microalgae from the class Haptophyceae, recognized as a natural rich source of EPA and DHA that are accumulated as oil droplets in prominent lipid bodies in the cell (Liu \& Lin, 2001; Yongmanitchai \& Ward, 1989). Dv is an important nutritional feedstock in aquaculture (Jeffrey, Brown, \& Volkman, 1994), being rich in fatty acids especially $\omega 3$ PUFA (including EPA and DHA). In addition, stanols and sterols structurally unique $(5 \alpha(\mathrm{H})$-stanols, 4desmethylsterols, $4 \alpha$-methylsterols) and pavlovols (3,4-dihydroxy$4 \alpha$-methylsterol, 3,4-dihydroxy-4 $\alpha$-ethylsterols), were also found is this microalga (Ghosh, Patterson, \& Wikfors, 1998; Ponis, Probert, Véron, Mathieu, \& Robert, 2006; Trautwein et al., 2002; Volkman, 2003; Volkman et al., 1998; Volkman, Farmer, \& Barrett, 1997; Xu, Yan, \& Wang, 2004). The golden-brown flagellate I. galbana is another important marine microalgae, as well as its favourable lipid composition (rich in $\omega 3$ PUFA). This Haptophyta is of substantial interest in aquaculture, principally to feed mollusk larvae, as well as fish and crustaceans in the early stages of growth (Pernet, Tremblay, Demers, \& Roussy, 2003; Poisson \& Ergan, 2001; Renaud, Thinh, Lambrinidis, \& Parry, 2002; Sánchez, Martínez, \& Espinola, 2000; Saoudi-Helis, Dubacq, Marty, Samain, \& Gudin, 1994). Other important biomolecules such as sterols, tocopherols, pigments and pharmaceuticals, among others, are also synthesized by this microalga (Fabregas \& Herrero, 1990; Flynn, Zapata, Garrido, Opik, \& Hipkin, 1993; Volkman, Smith, Eglinton, Forsberg, \& Corner, 1981).

In recent years, several products enriched with carotenoid and polyunsaturated fatty acids prepared from microalgae biomass have been developed, namely emulsions (Batista, Raymundo, Sousa, \& Empis, 2006; Batista, Raymundo, Sousa, Empis, \& Franco, 2006; Gouveia, Batista, Raymundo, Sousa, \& Empis, 2006; Raymundo, Gouveia, Batista, Empis, \& Sousa, 2005), gelled desserts (Batista, Gouveia, Nunes, Franco, \& Raymundo, 2008; Gouveia, Batista, Raymundo, \& Bandarra, 2008), biscuits (Gouveia, Batista, Miranda, Empis, \& Raymundo, 2007; Gouveia, Coutinho, et al., 2008) and pasta (Fradique et al., 2010).

The aim of the present study is to prepare fresh spaghetti enriched with different amounts of Dv and Ig as natural source of w3 PUFA, and to compare their fatty acid profile before and after the cooking process, in order to conclude about their stability to the thermal process. The effect of this incorporation on the sensorial attributes of the pasta was also evaluated, as well as on the proximate composition and cooking quality parameters.

\section{Materials and methods}

\subsection{I. galbana and D. vlkianum production}

I. galbana (Ig) and D. vlkianum (Dv) used in this study were obtained from Mary Park collection (Plymouth Laboratory, UK) and cultivated in INRB/L-IPIMAR. The microalgae were grown in $100 \mathrm{~L}$ plastic airlift bioreactors with bubbling air in seawater enriched with Miquel's Medium and Wallerstein's Medium (Vonshak, 1986) in the ratio 3:1 with $\mathrm{NaNO}_{3}$ and $\mathrm{KNO}_{3}$ used as nitrogen source and $\mathrm{NaH}_{2} \mathrm{PO}_{4}$ and $\mathrm{K}_{2} \mathrm{PO}_{4}$ as phosphorous supply. All solutions were autoclaved at $121{ }^{\circ} \mathrm{C}$ for $20 \mathrm{~min}$. The vitamin solution $\mathrm{B}_{1}$ and $\mathrm{B}_{12}$ were sterilized with $0.22 \mu \mathrm{m}$ filter. The culture was kept illuminated with fluorescent lamps (Philips TLM 40W/54RS) at an irradiance level of $196 \mu \mathrm{mol} \mathrm{m} \mathrm{m}^{-2} \mathrm{~s}^{-1}$ with photoperiod 24:0 h (L:D). The culture was continuously stirred by filtered air and all cultures were kept at $18 \pm 1{ }^{\circ} \mathrm{C}$ under continuously controlled conditions. The culture salinity was $25 \mathrm{~g} / \mathrm{L}$. Growth was monitored with an automatic counter Coulter EPICS XL from Beckman Company (Miami, FL, USA).

The microalgae biomass was recovered in the stationary growth phase without flocculation by simply stopping agitation, concentrated by centrifugation and freeze-drying.

\subsection{Fresh pasta production}

Fresh pasta was produced from commercial durum semolina flour (Cerealis, Maia, Portugal), water and microalgae biomass 0.5 , 1.0 and $2.0 \mathrm{~g} / 100 \mathrm{~g}$ DW. The mixture was extruded as spaghetti (1.5 mm diameter, $200 \mathrm{~mm}$ length) using a benchtop pasta maker (Biffinet, Verona, Italy). The pastas were dried at $60{ }^{\circ} \mathrm{C}$ for $5 \mathrm{~min}$, until final moisture of 30-32 g/100 g. Pasta without microalgae biomass (control) was also prepared.

The pastas cooking quality parameters - optimal cooking time, cooking losses, swelling index, water absorption and moisture were determined ( 5 replications) according to Brennan et al. (2003) and Fradique et al. (2010). Portions of $0.01 \mathrm{~kg}(10 \mathrm{~g})$ of each pasta were cooked in $100 \mathrm{~mL}$ boiling distilled water and analyzed every minute until optimum cooking time, considered as the time necessary to obtain complete gelatinization of starch, shown by the disappearance of the white central core, after having pressed the spaghetti strand between two transparent glass slides (Brennan et al., 2003; Edwards, Izydorczyk, Dexter, \& Biliaderis, 1993; Tudorica et al., 2002).

\subsection{Proximate analysis}

Microalgal biomass and pasta (raw and cooked) proximate chemical composition was performed according to the methods of AOAC (2006): dry weight (DW) after drying in an oven at $105{ }^{\circ} \mathrm{C}$ until constant weight; total ash content by incineration at $550{ }^{\circ} \mathrm{C}$ in 
a muffle for $12 \mathrm{~h}$ after controlled (slow) carbonization in a heating plate; crude protein $(\mathrm{N} \times 6.25)$ by the Kjeldahl method after acid digestion; fat content by Soxhlet extraction with petroleum ether. All the analysis were done in triplicate.

Fatty acid methyl esters (FAMEs) were prepared according to Lepage and Roy (1986) as modified by Cohen, Vonshak, and Richmond (1988). The FAMEs preparation was carried out using freeze-dried material and $5 \mathrm{~mL}$ of the acetyl chloride-methanol mixture $(1: 19 \mathrm{v} / \mathrm{v})$. The esterification was carried out at $80{ }^{\circ} \mathrm{C}$ over a $1 \mathrm{~h}$ period. After cooling, $1 \mathrm{~mL}$ of water and $2 \mathrm{~mL}$ of $n$ heptane were added to the mixture, which was stirred and centrifuged at $2150 \times \mathrm{g}$ for $10 \mathrm{~min}$. The organic phase was collected, filtered and dried over anhydrous sodium sulphate. Solvent was removed under nitrogen and the FAMEs dissolved in $0.1 \mathrm{~mL}$ of $n$ heptane. The analysis was performed by using a Varian CP 3800 (Walnut Creek, CA, USA) gas chromatograph equipped with an auto sampler and fitted with a flame ionization detector at $250{ }^{\circ} \mathrm{C}$. The separation was achieved using a capillary column of polietilenoglycol (DB-WAX (J\&W Agilent) $0.25 \mathrm{~mm}$ i.d.; $30 \mathrm{~m} \times 0.25 \mu \mathrm{m}$ ). After holding at $180{ }^{\circ} \mathrm{C}$ for $5 \mathrm{~min}$, the temperature was ramped at $4{ }^{\circ} \mathrm{C} /$ min to $220^{\circ} \mathrm{C}$, maintained at $220^{\circ} \mathrm{C}$ for 25 min with the injector at $250{ }^{\circ} \mathrm{C}$. The split ratio was $1: 100$. The fatty acid methyl esters were identified by comparison with the retention time of individual standards (Sigma, St. Louis, USA). The quantification was done by using the internal standard (21:0). All analytical determinations were done in triplicate.

\subsection{Sensory evaluation}

A sensory evaluation of the fresh pastas containing microalgae biomass, as well as the control semolina pasta, was conducted in order to evaluate the impact of microalgal biomass incorporation on the sensorial performance and to obtain a representative value of some quality parameters of the pastas.

An untrained panel of 41 individuals ( 33 female and 8 male, age range from 19 to 48 years old) tested cooked pastas, which had undergone the optimal cooking time (3-5 min) for the most representative sensory attributes - colour, odour, flavour and texture - on a $10 \mathrm{~cm}$ continuous scale. The score signed by each panellist was evaluated with a ruler and the final score was calculated as the mean value.

Each fresh pasta formulation was cooked and served immediately in white plastic plates. Samples were served in random order to the panellists, whom were asked to taste and rate the attributes, from don't like to like a lot, on a $10 \mathrm{~cm}$ line. Numerical assessments of the panellist responses were made by measuring the distance from the left of the response line in centimetres.

\subsection{Statistical analysis}

ANOVA-Post Hoc Comparisons-Scheffé test, at 0.05 probability level, using StatSoft STATISTICA program, version 6.0 (2001), was performed on all results.

\section{Results and discussion}

\subsection{Microalgal biomass and pasta composition}

The chemical proximate composition of freeze-dried microalgae was determined and the results are presented in Table 1

Table 2 shown the main classes of fatty acids present in the microalgae biomass. Among fatty acids PUFA were the dominant group in both microalgae, being EPA $(20: 5 \omega 3)$ the main fatty acid followed by DHA (22:6w3).

The chemical proximate composition and fatty acid profile ( $\mathrm{mg} /$ $100 \mathrm{~g}$ ) of raw and cooked control pasta were carried out and the results are presented in Table 1 and Table 2, respectively.

PUFA's were the dominant group representing $58 \%$ of total fatty acids. Among PUFA, $\omega 6$ were present in $54 \%$ and $\omega 3$ in $3 \%$. Linoleic acid (18:2 $\omega 6)$ was the major fatty acid in the pasta and attained around $93 \%$ of total PUFA Saturated fatty acids (SFA) and monounsaturated fatty acids (MUFA) represent $24 \%$ and $21 \%$, respectively, of total fatty acids. After cooking the control pasta in the optimal cooking time, previously determined as being $5 \mathrm{~min}$, fatty acid profile did not change significantly $(p<0.05)$.

Pasta prepared with Ig incorporation is presented in Fig. 1a and the effect of microalgal biomass concentration of $\mathrm{Dv}$ is present in Fig. 1b. The microalgae enriched pasta had an appealing colour, increasing colour intensity with concentration (Dv) (Fig. 1b).

The pastas cooking quality parameters - optimal cooking time, cooking losses, swelling index, water absorption and moisture are presented in Table 3.

Optimal cooking time depends primarily on the rates of water penetration and starch gelatinization (Edwards et al., 1993). Pastas prepared with microalgae biomass incorporation exhibited an optimal cooking time, slightly lower than the control.

Cooking losses are an important indicator of the overall spaghetti cooking performance by both consumers and industry (Brennan et al., 2003) being mainly influenced by dissolving and releasing gelatinized starches from the surface of pasta through cooking water. The inclusion of microalgae in pasta slightly induces a reduction $(p<0.05)$ of cooking losses, presenting values around $3-6 \%$. Considering that cooking loss values lower than $7-8 \%$ are expected for semolina spaghettis (Doxastakis et al., 2007), the pastas elaborated in the present study can be regarded as high quality fresh pastas.

Pastas prepared with microalgae present swelling indexes lower than control as well as water absorption.

The major fatty acids (\% of total fatty acids) in raw and cooked control pastas and enriched with $0.5,1.0$ and $2.0 \mathrm{~g} / 100 \mathrm{~g}$ DW of Ig and Dv biomass incorporation are presented in terms of \% (Table 4 and Table 5) and $\mathrm{mg} / 100 \mathrm{~g}$ (Table 6 and Table 7). The results indicate a skewed ratio of $\omega 3$ and $\omega 6$ fatty acids at $1: 25(w / w)$. In general, it is considered that a healthy diet should have a $\omega 3 / \omega 6$ ratio about $1: 2$ to $1: 4(\mathrm{w} / \mathrm{w})$ (Gebauer, Harris, Kris-Etherton, \& Etherton, 2004; Simopoulos, 2002). Incorporation of microalgae led

Table 1

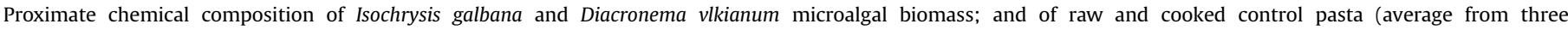
replicates \pm standard deviation).

\begin{tabular}{|c|c|c|c|c|}
\hline & Isochrysis galbana & Diacronema vlkianum & Control raw & Pasta cooked \\
\hline Dry weight (g/100 g) & $96.0 \pm 0.1$ & $91.3 \pm 0.01$ & $31.1 \pm 0.7$ & $30.4 \pm 0.2$ \\
\hline Total ash (g/100 g DW) & $14.5 \pm 0.1$ & $18.4 \pm 0.8$ & $1.7 \pm 0.1$ & $0.6 \pm 0.0$ \\
\hline Crude protein (g/100 g DW) & $39.6 \pm 0.3$ & $38.4 \pm 0.2$ & $13.3 \pm 0.4$ & $6.8 \pm 0.1$ \\
\hline Crude fat (g/100 g DW) & $23.9 \pm 0.02$ & $17.9 \pm 0.5$ & $1.9 \pm 0.1$ & $1.1 \pm 0.1$ \\
\hline Carbohydrates (g/100 g DW) & $18^{\mathrm{a}}$ & $17^{\mathrm{a}}$ & $14.2^{\mathrm{a}}$ & $21.9^{\mathrm{a}}$ \\
\hline
\end{tabular}

Different letters in the same row correspond to significant differences $(p<0.05$ ).

a Calculated by difference. 
Table 2

Main fatty acids (mg/100 $\mathrm{g} \mathrm{DW}$ ) present in the microalgae biomass and in raw and cooked control pasta (average from three replicates \pm standard deviation).

\begin{tabular}{lll}
\hline Fatty acids (mg/100 g DW) & Isochrysis galbana & Diacronema vlkianum \\
\hline $14: 0$ & $3272 \pm 3$ & $1971 \pm 38$ \\
$16: 0$ & $2711 \pm 6$ & $1320 \pm 10$ \\
Other SFA & $698 \pm 51$ & $296 \pm 5$ \\
$\sum$ SFA & 6681 & 3587 \\
& & \\
$16: 1$ & $3275 \pm 3$ & $2425 \pm 41$ \\
$18: 1$ & $513 \pm 1$ & $253 \pm 5$ \\
Other MUFA & $425 \pm 18$ & $943 \pm 82$ \\
$\sum$ MUFA & 4213 & 3621 \\
18:3 $\omega 3-$ ALA & & $14 \pm 1$ \\
$20: 5 \omega 3-$ EPA & $421 \pm 5$ & $3212 \pm 57$ \\
$22: 6 \omega 3-$ DHA & $4875 \pm 108$ & $836 \pm 41$ \\
Other PUFA- $\omega 3$ & $1156 \pm 40$ & $1346 \pm 47$ \\
$18: 2 \omega 6$ & - & $49 \pm 5$ \\
$18: 3 \omega 6$ & $123 \pm 1$ & $112 \pm 3$ \\
Other PUFA- $\omega 6$ & - & $1182 \pm 23$ \\
$\sum$ PUFA & $2278 \pm 75$ & 6751 \\
$\omega 3 / \omega 6$ & 8853 & 4.1 \\
\hline
\end{tabular}

to increased levels of $\omega 3$ fatty acids finally bringing down the ratio of $\omega 3$ to $\omega 6$ from $1: 15$ to $1: 13-1: 17$ for Dv raw pastas (Dv cooked pastas $-1: 13-1: 18$ ) and $1: 6-1: 11$ for Ig raw pastas (Ig cooked pastas - 1:5-1:11). This has also been observed for wakame (Undaria pinnatifida) enriched semolina pastas, reported by Prabhasankar et al. (2009).

Skewed $\omega 3 / \omega 6$ ratio outcome from the low amount of $\omega 3$ PUFA in raw pasta, while microalgae pastas contained higher level of EPA and DHA, due to the fatty acid profile of Ig and Dv microalgae (Table 2) as it was also reported by Bandarra, Pereira, Batista, and Vilela (2003) and Donato, Vilela, and Bandarra (2003).
Palmitic acid (16:0) was the main SFA present in Ig (Tables 4 and 6 ) and Dv (Tables 5 and 7 ) raw pastas, while oleic acid (18:1 $\omega 9)$ was the most important MUFA detected in Ig and Dv pastas. The highest values were recorded for the Dv raw pastas (15-16\%).

Among PUFA's fraction, $\omega 3$ fatty acids were the dominant group with linoleic acid (18:2 $\omega 6)$ being the major fatty acid present in raw and cooked control, as well as in Ig (Tables 4 and 6) and Dv (Tables 5 and 7) raw and cooked pastas. This is in accordance with durum wheat semolina pastas fatty acid profile reported by other authors (Bellegia, Platani, Spano, Monteleone, \& Cattivelli, 2009; Iafelice et al., 2008; Prabhasankar et al., 2009), being palmitic acid (16:0), oleic acid (18:1 $\omega 9)$ and $\alpha$-linolenic acid (18:3 $\omega 3)$ the other major fatty acids. This predominance (over $50 \%$ ) of $\omega 6$ linoleic acid in grain cereals is a major contribution to the imbalanced $\omega 3$ / $\omega 6$ ratio consumption in western diets.

The enrichment of raw control fresh pastas with Ig and Dv biomass led to significant increase of EPA and DHA that were absent in raw control pastas.

Increasing microalgae biomass (Ig and Dv) incorporation level in raw pastas, from 0.5 to $2.0 \mathrm{~g} / 100 \mathrm{~g} \mathrm{DW}$, led to a significant increase $(p<0.05)$ of EPA (Ig raw pastas: $1.2-3.3 \%$; Dv raw pastas: $0.3-0.6 \%$ ) and DHA (Ig raw pastas: $0.3-0.9 \%$; Dv raw pastas: $0.1 \%$ ).

A number of countries (Canada, Sweden, United Kingdom, Australia, Japan), as well as the World Health Organization and North Atlantic Treaty Organization have made formal populationbased dietary recommendations for omega- 3 fatty acids. Typical recommendations are $0.3-0.5 \mathrm{~g} /$ day of EPA + DHA and $0.8-1.1 \mathrm{~g} /$ day of ALA (Welch et al., 2003). The Acceptable Macronutrient Distribution Range (AMDR) for ALA is estimated to be $0.6 \%-1.2 \%$ of energy, or $1.3-2.7 \mathrm{~g} /$ day on the basis of a 2000-calorie diet which is nearly 10 times the current intake of EPA + DHA (Kris-Etherton et al., 2003). These recommendations can easily be achieved by following the American Heart Association Dietary Guidelines, consuming two fish meals per week, with an emphasis on fatty fish (i.e., salmon, herring and mackerel) and using liquid vegetable oils containing ALA (Kris-Etherton et al., 2003). In this way, the addition
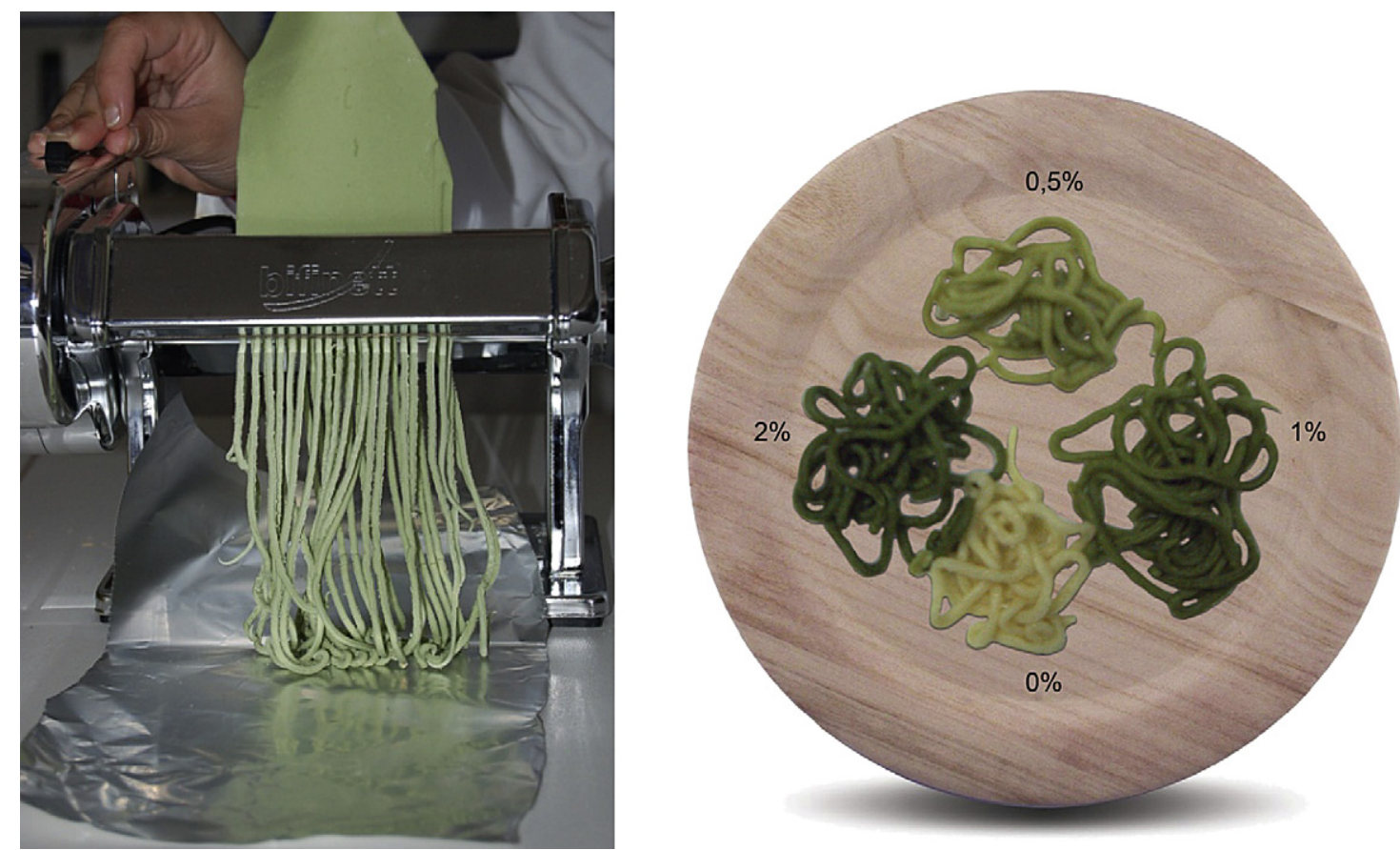

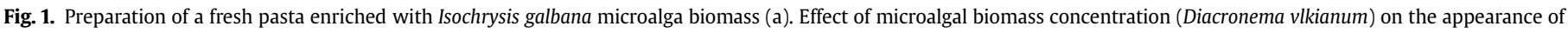
fresh pasta (b). 
Table 3

- Cooking quality attributes of pastas with Isochrysis galbana (Ig) and Diacronema vlkianum (Dv) incorporation (average from five replicates \pm standard deviation).

\begin{tabular}{|c|c|c|c|c|c|}
\hline & Optimal cooking time (min) & Cooking loss (\%) & Swelling index (g water/g DW) & Water absorption (\%) & Moisture (g/100 g) \\
\hline $0.0 \mathrm{~g} / 100 \mathrm{~g}$ & 5 & $5.6 \pm 0.4$ & $1.8 \pm 0.1$ & $98.2 \pm 1.0$ & $30.4 \pm 0.2$ \\
\hline $0.5 \mathrm{~g} / 100 \mathrm{~g} \mathrm{Ig}$ & 5 & $4.2 \pm 0.4$ & $1.6 \pm 0.2$ & $95.9 \pm 0.3$ & $29.7 \pm 2.7$ \\
\hline $1 \mathrm{~g} / 100 \mathrm{~g} \mathrm{Ig}$ & 4 & $4.4 \pm 0.5$ & $1.6 \pm 0.4$ & $87.6 \pm 3.2$ & $32.0 \pm 0.6$ \\
\hline $2 \mathrm{~g} / 100 \mathrm{~g} \mathrm{Ig}$ & 3 & $3.9 \pm 0.0$ & $1.6 \pm 0.1$ & $81.9 \pm 4.2$ & $32.1 \pm 2.3$ \\
\hline $0.5 \mathrm{~g} / 100 \mathrm{~g} \mathrm{Dv}$ & 5 & $4.3 \pm 0.4$ & $1.2 \pm 0.2$ & $95.1 \pm 0.3$ & $33.0 \pm 1.3$ \\
\hline $1 \mathrm{~g} / 100 \mathrm{~g} \mathrm{Dv}$ & 4 & $4.4 \pm 0.5$ & $1.1 \pm 0.2$ & $87.7 \pm 3.2$ & $30.6 \pm 0.3$ \\
\hline $2 \mathrm{~g} / 100 \mathrm{~g} \mathrm{Dv}$ & 3 & $3.9 \pm 0.1$ & $0.9 \pm 0.1$ & $82.0 \pm 4.2$ & $30.6 \pm 0.8$ \\
\hline
\end{tabular}

Table 4

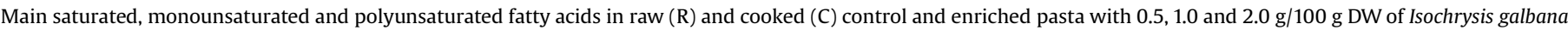
biomass (Ig). Expressed as average values (three replicates) of the percent of total fatty acids.

\begin{tabular}{|c|c|c|c|c|c|c|c|c|}
\hline \multirow[t]{2}{*}{ Fatty acids (\%) } & \multicolumn{2}{|l|}{ Control } & \multicolumn{6}{|c|}{$\operatorname{Ig}(\mathrm{g} / 100 \mathrm{~g})$} \\
\hline & (R) & (C) & $0.5(\mathrm{R})$ & $1.0(\mathrm{R})$ & $2.0(\mathrm{R})$ & $0.5(\mathrm{C})$ & $1.0(\mathrm{C})$ & $2.0(\mathrm{C})$ \\
\hline $14: 0$ & $0.14^{\mathrm{a}}$ & $0.14^{\mathrm{a}}$ & $0.79^{\mathrm{b}}$ & $1.35^{\mathrm{c}}$ & $2.14^{\mathrm{d}}$ & $0.69^{\mathrm{b}}$ & $1.22^{\mathrm{c}}$ & $2.10^{\mathrm{d}}$ \\
\hline $16: 0$ & $21.75^{a}$ & $20.46^{\mathrm{a}}$ & $23.11^{\mathrm{a}}$ & $23.67^{\mathrm{a}}$ & $20.58^{a}$ & $22.98^{a}$ & $17.95^{\mathrm{a}}$ & $18.55^{\mathrm{a}}$ \\
\hline 18:0 & $1.49^{\mathrm{b}}$ & $1.26^{\mathrm{ab}}$ & $1.56^{\mathrm{b}}$ & $1.59^{\mathrm{b}}$ & $1.25^{\mathrm{ab}}$ & $1.51^{\mathrm{b}}$ & $0.97^{\mathrm{a}}$ & $1.02^{\mathrm{a}}$ \\
\hline Other SFA & 0.53 & 0.37 & 0.57 & 0.70 & 0.74 & 0.75 & 1.08 & 0.65 \\
\hline$\sum \mathrm{SFA}$ & 23.96 & 22.28 & 26.03 & 27.31 & 24.71 & 25.93 & 21.22 & 22.32 \\
\hline $16: 1$ & $0.13^{\mathrm{a}}$ & $0.14^{\mathrm{a}}$ & $0.11^{\mathrm{b}}$ & $0.11^{\mathrm{a}}$ & $0.09^{\mathrm{ab}}$ & $0.14^{\mathrm{ab}}$ & $0.12^{\mathrm{ab}}$ & $0.11^{\mathrm{ab}}$ \\
\hline $18: 1$ & $17.65^{d}$ & $16.63^{\mathrm{cd}}$ & $15.15^{\mathrm{bc}}$ & $13.97^{\mathrm{ab}}$ & $13.63^{\mathrm{ab}}$ & $14.32^{\mathrm{ab}}$ & $13.23^{\mathrm{ab}}$ & $12.29^{a}$ \\
\hline Other MUFA & 2.27 & 1.82 & 1.56 & 0.99 & 1.11 & 0.86 & 0.76 & 0.80 \\
\hline$\sum M U F A$ & 21.22 & 19.64 & 19.09 & 18.27 & 19.46 & 17.38 & 17.01 & 17.65 \\
\hline $18: 2 \omega 6-\mathrm{LA}$ & $50.11^{\mathrm{ab}}$ & $53.01^{\mathrm{b}}$ & $48.51^{\mathrm{ab}}$ & $46.82^{\mathrm{a}}$ & $45.49^{\mathrm{a}}$ & $50.68^{\mathrm{ab}}$ & $52.86^{\mathrm{b}}$ & $46.57^{\mathrm{a}}$ \\
\hline $18: 3 \omega 3-$ ALA & $2.63^{a}$ & $2.99^{\mathrm{a}}$ & $2.56^{\mathrm{a}}$ & $2.55^{\mathrm{a}}$ & $2.53^{\mathrm{a}}$ & $2.78^{\mathrm{a}}$ & $3.12^{\mathrm{a}}$ & $2.83^{\mathrm{a}}$ \\
\hline $20: 5 \omega 3-\mathrm{EPA}$ & - & - & $1.19^{\mathrm{b}}$ & $2.11^{c}$ & $3.29^{d}$ & $1.12^{\mathrm{b}}$ & $2.44^{\mathrm{c}}$ & $4.11^{\mathrm{e}}$ \\
\hline $22: 6 \omega 3$ - DHA & - & - & $0.27^{\mathrm{b}}$ & $0.48^{c}$ & $0.91^{\mathrm{e}}$ & $0.33^{\mathrm{b}}$ & $0.63^{d}$ & $1.13^{f}$ \\
\hline Other PUFA & 0.87 & 0.72 & 0.94 & 0.87 & 1.57 & 0.72 & 1.03 & 1.77 \\
\hline$\sum$ PUFA & 53.61 & 56.72 & 53.47 & 52.83 & 53.79 & 55.63 & 60.08 & 56.41 \\
\hline$\omega 3$ & $3.51^{\mathrm{a}}$ & $3.66^{\mathrm{ab}}$ & $4.50^{\mathrm{abc}}$ & $5.65^{c}$ & $7.65^{d}$ & $4.65^{\mathrm{bc}}$ & $7.05^{d}$ & $9.20^{\mathrm{e}}$ \\
\hline$\omega 6$ & $54.22^{\mathrm{a}}$ & $56.49^{a}$ & $48.70^{\mathrm{a}}$ & $47.05^{\mathrm{a}}$ & $45.80^{\mathrm{a}}$ & $50.85^{\mathrm{a}}$ & $53.15^{\mathrm{a}}$ & $47.00^{\mathrm{a}}$ \\
\hline$\omega 3 / \omega 6$ & $1: 15$ & $1: 15$ & $1: 11$ & $1: 8$ & $1: 6$ & $1: 11$ & $1: 8$ & $1: 5$ \\
\hline
\end{tabular}

Different letters in the same row correspond to significant differences $(p<0.05)$.

Table 5

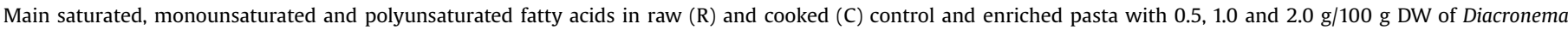
vlkianum biomass (Dv). Expressed as average values (three replicates) of the percent of total fatty acids.

\begin{tabular}{|c|c|c|c|c|c|c|c|c|}
\hline \multirow[t]{2}{*}{ Fatty acids (\%) } & \multicolumn{2}{|l|}{ Control } & \multicolumn{6}{|c|}{$\underline{\mathrm{Dv}}(\mathrm{g} / 100 \mathrm{~g})$} \\
\hline & (R) & (C) & $0.5(\mathrm{R})$ & $1.0(\mathrm{R})$ & $2.0(\mathrm{R})$ & $0.5(\mathrm{C})$ & $1.0(\mathrm{C})$ & $2.0(\mathrm{C})$ \\
\hline $14: 0$ & $0.14^{\mathrm{a}}$ & $0.14^{\mathrm{a}}$ & $0.73^{\mathrm{b}}$ & $1.17^{\mathrm{c}}$ & $2.06^{\mathrm{d}}$ & $0.56^{\mathrm{b}}$ & $1.21^{\mathrm{c}}$ & $2.09^{\mathrm{d}}$ \\
\hline $16: 0$ & $21.75^{a}$ & $21.75^{a}$ & $21.68^{a}$ & $23.16^{\mathrm{a}}$ & $21.78^{\mathrm{a}}$ & $23.17^{\mathrm{a}}$ & $19.43^{a}$ & $18.67^{\mathrm{a}}$ \\
\hline 18:0 & $1.49^{\mathrm{b}}$ & $1.49^{\mathrm{b}}$ & $1.64^{\mathrm{a}}$ & $1.60^{\mathrm{a}}$ & $1.35^{\mathrm{a}}$ & $1.69^{\mathrm{a}}$ & $1.09^{\mathrm{a}}$ & $1.04^{\mathrm{a}}$ \\
\hline Other SFA & 0.53 & 0.53 & 0.62 & 0.71 & 0.78 & 0.58 & 0.66 & 0.89 \\
\hline$\sum \mathrm{SFA}$ & 23.96 & 23.96 & 24.68 & 26.64 & 25.97 & 26.00 & 22.40 & 22.69 \\
\hline $16: 1$ & $0.13^{\mathrm{a}}$ & $0.13^{\mathrm{a}}$ & $0.21^{\mathrm{a}}$ & $0.14^{\mathrm{a}}$ & $0.16^{\mathrm{a}}$ & $0.16^{\mathrm{a}}$ & $0.16^{\mathrm{a}}$ & 0.18 \\
\hline $18: 1$ & $17.65^{d}$ & $17.65^{\mathrm{d}}$ & $16.50^{\mathrm{bc}}$ & $15.56^{\mathrm{dbc}}$ & $14.92^{\mathrm{ab}}$ & $16.56^{\mathrm{bc}}$ & $14.73^{\mathrm{ab}}$ & $13.91^{\mathrm{a}}$ \\
\hline Other MUFA & 2.27 & 2.27 & 1.29 & 1.25 & 1.28 & 1.13 & 1.18 & 0.96 \\
\hline$\sum$ MUFA & 21.22 & 21.22 & 19.53 & 19.16 & 19.47 & 19.38 & 18.06 & 17.93 \\
\hline $18: 2 \omega 6-\mathrm{LA}$ & $50.11^{\mathrm{ab}}$ & $50.11^{\mathrm{ab}}$ & $51.25^{\mathrm{ab}}$ & $49.44^{\mathrm{ab}}$ & $48.31^{\mathrm{a}}$ & $50.47^{\mathrm{ab}}$ & $54.11^{\mathrm{b}}$ & $52.81^{\mathrm{ab}}$ \\
\hline $18: 3 \omega 3-$ ALA & $2.63^{\mathrm{a}}$ & $2.63^{\mathrm{a}}$ & $2.53^{\mathrm{a}}$ & $2.51^{\mathrm{a}}$ & $2.52^{\mathrm{a}}$ & $2.33^{\mathrm{a}}$ & $2.98^{\mathrm{a}}$ & 2.95 \\
\hline $20: 5 \omega 3-E P A$ & - & - & $0.30^{\mathrm{bc}}$ & $0.41^{\mathrm{c}}$ & $0.66^{\mathrm{e}}$ & $0.22^{\mathrm{b}}$ & $0.48^{\mathrm{cd}}$ & $0.64^{\text {de }}$ \\
\hline $22: 6 \omega 3-\mathrm{DHA}$ & - & - & - & - & $0.12^{\mathrm{a}}$ & - & $0.04^{\mathrm{a}}$ & $0.11^{\mathrm{a}}$ \\
\hline Other PUFA & 0.87 & 0.87 & 0.53 & 0.51 & 0.59 & 0.48 & 0.62 & 0.62 \\
\hline$\sum$ PUFA & 53.61 & 53.61 & 54.61 & 52.87 & 52.21 & 53.50 & 58.27 & 57.13 \\
\hline$\omega 3$ & $3.51^{\mathrm{a}}$ & $3.51^{\mathrm{a}}$ & $3.10^{\mathrm{ab}}$ & $3.10^{\mathrm{ab}}$ & $3.65^{\mathrm{ab}}$ & $2.75^{\mathrm{a}}$ & $3.80^{\mathrm{ab}}$ & $4.00^{\mathrm{b}}$ \\
\hline$\omega 6$ & $54.22^{\mathrm{a}}$ & $54.22^{\mathrm{a}}$ & $51.35^{\mathrm{a}}$ & $49.55^{\mathrm{a}}$ & $48.45^{\mathrm{a}}$ & $50.60^{\mathrm{a}}$ & $54.25^{\mathrm{a}}$ & $53.00^{\mathrm{a}}$ \\
\hline$\omega 3 / \omega 6$ & $1: 15$ & $1: 15$ & $1: 15$ & $1: 15$ & $1: 13$ & $1: 18$ & $1: 13$ & $1: 13$ \\
\hline
\end{tabular}

Different letters in the same row correspond to significant differences $(p<0.05)$. 
Table 6

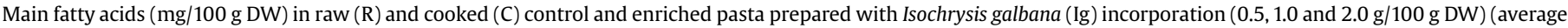
from three replicates).

\begin{tabular}{|c|c|c|c|c|c|c|c|c|}
\hline \multirow[t]{2}{*}{ Fatty acids (mg/100 g DW) } & \multicolumn{2}{|l|}{ Control } & \multicolumn{6}{|c|}{$\operatorname{Ig}(\mathrm{g} / 100 \mathrm{~g})$} \\
\hline & $(\mathrm{R})$ & (C) & $0.5(\mathrm{R})$ & $1.0(\mathrm{R})$ & $2.0(\mathrm{R})$ & $0.5(\mathrm{C})$ & $1.0(\mathrm{C})$ & $2.0(\mathrm{C})$ \\
\hline $14: 0$ & 2.7 & 1.5 & 14.9 & 25.5 & 40.4 & 7.2 & 12.9 & 22.1 \\
\hline $16: 0$ & 411.7 & 215.1 & 437.5 & 448.1 & 389.5 & 241.7 & 188.7 & 195.1 \\
\hline $18: 0$ & 29.1 & 13.8 & 29.5 & 30.0 & 23.7 & 15.8 & 10.2 & 10.7 \\
\hline Other SFA & 10.1 & 3.9 & 10.6 & 13.3 & 13.9 & 7.9 & 11.3 & 6.7 \\
\hline$\sum S F A$ & 453.6 & 234.3 & 492.5 & 516.9 & 467.5 & 272.6 & 223.1 & 234.6 \\
\hline $16: 1$ & 6.8 & 3.6 & 24.1 & 39.4 & 64.0 & 12.1 & 20.7 & 34.8 \\
\hline $18: 1$ & 352.1 & 183.9 & 307.9 & 287.8 & 283.5 & 161.7 & 150.2 & 142.4 \\
\hline Other MUFA & 43 & 19.1 & 29.4 & 18.9 & 20.8 & 9 & 8 & 8.5 \\
\hline$\sum M U F A$ & 401.9 & 206.6 & 361.4 & 346.1 & 368.3 & 182.8 & 178.9 & 185.7 \\
\hline $18: 2 \omega 6-$ LA & 948.6 & 557.4 & 918.2 & 886.2 & 861.0 & 533.0 & 555.9 & 489.8 \\
\hline $18: 3 \omega 3-$ ALA & 0.6 & 0.4 & 48.5 & 48.2 & 47.9 & 29.3 & 32.9 & 29.7 \\
\hline $20: 5 \omega 3-\mathrm{EPA}$ & 0.0 & 0.0 & 22.5 & 39.9 & 62.2 & 11.8 & 25.7 & 43.3 \\
\hline $22: 6 \omega 3-$ DHA & 0.0 & 0.0 & 5.1 & 9.1 & 17.2 & 3.5 & 6.6 & 11.9 \\
\hline Other PUFA & 75.3 & 43.4 & 17.4 & 16.3 & 29.7 & 7.5 & 10.9 & 18.6 \\
\hline$\sum$ PUFA & 1024.5 & 601.2 & 1011.7 & 999.7 & 1018.0 & 585.1 & 632.0 & 593.3 \\
\hline$\omega 3$ & 71.8 & 41.5 & 87.3 & 106.5 & 146.6 & 48.9 & 71.6 & 96.0 \\
\hline$\omega 6$ & 951.2 & 558.9 & 921.7 & 890.4 & 867.5 & 534.9 & 558.7 & 493.8 \\
\hline
\end{tabular}

of microalgae biomass to pasta products seems to be an interesting way to increase $\omega 3$ PUFA consumption through an economical and practical product like pastas. The ingestion of $100 \mathrm{~g}(0.1 \mathrm{~kg})$ of pastas enriched with biomass of $\mathrm{Ig}(0.5,1.0$ and $2.0 \mathrm{~g} / 100 \mathrm{~g})$ provides $3.1 \%, 6.5 \%$ and $11.0 \%$, respectively, of the recommended daily dose of EPA and DHA (500 mg/day (ISSFAL, 2004)), while the pastas with Dv biomass provides $0.5-2.0 \%$. These results confirm the importance of microalgae incorporation in traditional foods as a way to enrich the nutritional value by bioactive molecules.

\subsection{Sensory evaluation}

Sensory evaluation of pastas can be an important step to consider the possibility towards an industrial and commercial approach. The main sensory characteristics (colour, odour, flavour, texture and the global appreciation) of cooked fresh spaghetti determined by an untrained panel are reported in Fig. 2. The panel showed preference for the control semolina fresh pasta, however they have classified positively the pastas with microalgae incorporation $(0.5 \mathrm{~g} / 100 \mathrm{~g}$ microalgal biomass addition). The pastas prepared with the maximum incorporation $(2.0 \mathrm{~g} / 100 \mathrm{~g}$ DW) were the least appreciated, in terms of odour and texture. However, in terms of colour, tasters did not differentiate pastas prepared with different amounts of Dv. For the higher concentration of algae in pastas, both for Dv and Ig, the panel had identified a fishy taste and lead to a weak global appreciation.

To overcome the possible fish flavour of these microalgae enriched pastas, this product could be oriented to fish/marine pasta dishes and sauces markets.

Table 7

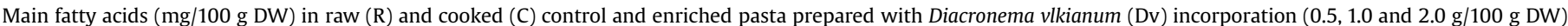
(average from three replicates).

\begin{tabular}{|c|c|c|c|c|c|c|c|c|}
\hline \multirow[t]{2}{*}{ Fatty acids (mg/100 g DW) } & \multicolumn{2}{|l|}{ Control } & \multicolumn{6}{|c|}{$\mathrm{Dv}(\mathrm{g} / 100 \mathrm{~g})$} \\
\hline & $(\mathrm{R})$ & (C) & $0.5(\mathrm{R})$ & $1.0(\mathrm{R})$ & $2.0(\mathrm{R})$ & $0.5(\mathrm{C})$ & $1.0(\mathrm{C})$ & $2.0(\mathrm{C})$ \\
\hline 14:0 & 2.7 & 1.5 & 13.7 & 22.2 & 39.0 & 5.8 & 12.7 & 21.9 \\
\hline $16: 0$ & 411.7 & 215.1 & 410.4 & 438.4 & 412.2 & 243.7 & 204.4 & 196.3 \\
\hline 18:0 & 29.1 & 13.8 & 31.1 & 30.4 & 25.6 & 17.7 & 11.5 & 11.0 \\
\hline Other SFA & 10.1 & 3.9 & 11.9 & 13.3 & 14.9 & 6.2 & 6.9 & 9.4 \\
\hline$\sum \mathrm{SFA}$ & 453.6 & 234.3 & 467.1 & 504.3 & 491.7 & 273.4 & 235.5 & 238.6 \\
\hline $16: 1$ & 6.8 & 3.6 & 17.2 & 26.4 & 44.9 & 8.6 & 15.0 & 24.7 \\
\hline $18: 1$ & 352.1 & 183.9 & 328.0 & 312.6 & 299.3 & 183.4 & 162.5 & 153.8 \\
\hline Other MUFA & 43 & 19.1 & 24.5 & 23.6 & 24.3 & 11.8 & 12.4 & 10.1 \\
\hline$\sum M U F A$ & 401.9 & 206.6 & 369.7 & 362.6 & 368.5 & 203.8 & 189.9 & 188.6 \\
\hline $18: 2 \omega 6-$ LA & 948.6 & 557.4 & 970.0 & 935.9 & 914.5 & 530.8 & 569.0 & 555.4 \\
\hline $18: 3 \omega 3-$ ALA & 0.6 & 0.4 & 47.9 & 47.4 & 47.8 & 24.5 & 31.3 & 31.0 \\
\hline $20: 5 \omega 3-E P A$ & 0.0 & 0.0 & 5.7 & 7.8 & 12.5 & 2.3 & 5.0 & 6.7 \\
\hline $22: 6 \omega 3-$ DHA & 0.0 & 0.0 & 0.0 & 1.3 & 2.3 & 0.0 & 0.9 & 1.2 \\
\hline Other PUFA & 75.3 & 43.4 & 10.1 & 8.4 & 11.1 & 5 & 6.5 & 6.5 \\
\hline$\sum$ PUFA & 1024.5 & 601.2 & 1033.7 & 1000.8 & 988.2 & 562.6 & 612.7 & 600.8 \\
\hline$\omega 3$ & 71.8 & 41.5 & 59.7 & 60.9 & 69.4 & 29.5 & 41.2 & 43.0 \\
\hline$\omega 6$ & 951.2 & 558.9 & 972.3 & 938.0 & 917.4 & 532.2 & 570.6 & 557.0 \\
\hline
\end{tabular}


a

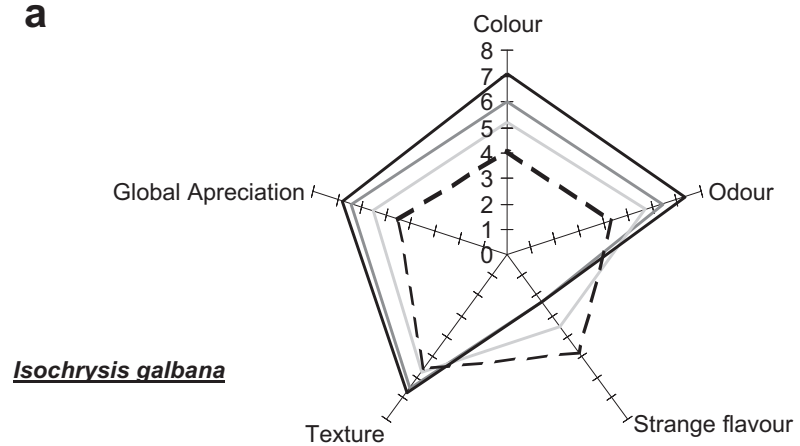

b

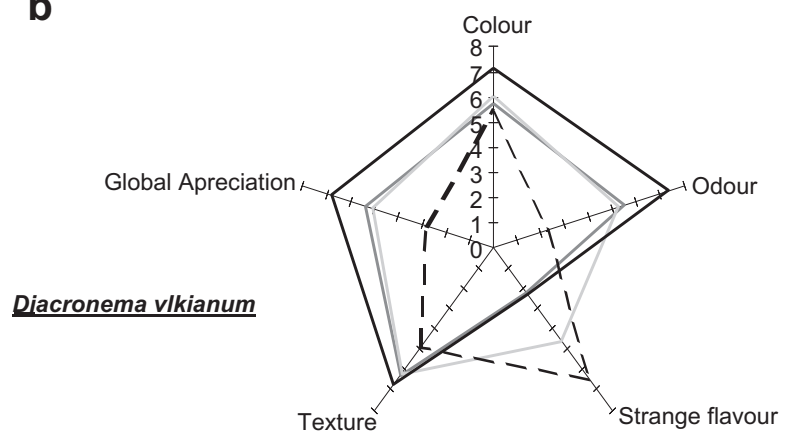

Fig. 2. Sensory evaluation of cooked fresh pasta prepared with $0.5(-), 1.0(-)$ and 2.0 (--) g/100 g DW of I. galbana (a) and D. vlkianum (b) biomass and control (-). Score 1 - dislike to 10 - like very much.

\section{Conclusions}

Pasta, very popular, convenient and well balanced nutritional food, can be enhanced with PUFA fatty acids, by the incorporation of the microalgal biomass, such as I. galbana and D. vlkianum.

Palmitic acid (16:0), oleic acid (18:1 $\omega 9)$ and linoleic acid (18:2 $\omega 6)$ were the main saturated, mono and polyunsaturated fatty acids, respectively, in both pastas prepared by microalgal biomass added. The enrichment of raw control fresh pastas with Ig and Dv biomass led also to a significant increase of eicosapentaenoic acid

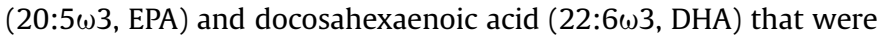
absent in raw control pastas.

These results confirm the importance of microalgae incorporation in traditional foods as a way to enrich their nutritional value by bioactive molecules.

The sensorial evaluation revealed a slight depreciative fish flavour for the pasta with higher microalgal biomass contents (2 g/ $100 \mathrm{~g}$ ). Nevertheless, fish based culinary preparations could take advantage of this point.

\section{Acknowledgements}

This work is part of a research project "Pigments antioxidants and PUFA's in microalgae based food products - functional implications" (PTDC/AGR-ALI/65926/2006) sponsored by the Portuguese Foundation for the Science and Technology ("Fundação para a Ciência e a Tecnologia" - FCT). Authors are also grateful to Cerealis SGPS, SA for their collaboration with the supply of the semolina samples used in this work.

\section{References}

A.O.A.C. (2006). Official methods of analysis. (18th ed.). Association of the Official Analytical Chemists.

Arteburn, L. A., Oke, H. A., Hoffman, J. P., Bailey-Hall, E., Cheng, G., Rom, D., et al. (2007). Bioequivalence of docosahexaenoic acid from different algal oils in capsules and in DHA-fortified food. Lipids, 42, 1011-1024.

Bandarra, N. M., Pereira, P. A., Batista, I., \& Vilela, M. H. (2003). Fatty acids sterols and $\alpha$-tocopherol in Isochrysis galbana. Journal of Food Lipids, 10, 25-34.

Barclay, W. R., Meager, K. M., \& Abril, J. R. (1994). Heterotrophic production of long chain omega-3 fatty acids utilizing algae and algae-like microorganisms. Journal of Applied Phycology, 6, 123-129.

Barrow, C. J., Nolan, C., \& Holub, B. J. (2009). Bioequivalence of encapsulated and microencapsulated fish-oil supplementation. Journal of Functional Foods, 1, 38-43.

Batista, A. P., Gouveia, L., Nunes, M. C., Franco, J. M., \& Raymundo, A. (2008). Microalgae biomass as a novel functional ingredient in mixed gel systems. In P. A. Williams, \& G. O. Phillips (Eds.), Gums and stabilisers for the food industry (pp. 487-494). Cambridge, UK: RSC Publishing.

Batista, A. P., Raymundo, A., Sousa, I., \& Empis, J. (2006). Rheological characterization of coloured oil in water food emulsions with lutein and phycocyanin added to the oil and aqueous phases. Food Hydrocolloids, 20, 44-52.

Batista, A. P., Raymundo, Sousa, I., Empis, J., \& Franco, J. M. (2006). Colored food emulsions - implications of pigment addition on the rheological behaviour and microstructure. Food Biophysics, 1, 216-227.

Belarbi, E. H., Molina, E., \& Chisti, Y. (2000). A process for high yield and scaleable recovery of high purity eicosapentaenoic acid esters from microalgae and fish oil. Enzyme Microbiology and Technology, 26, 516-529.

Bellegia, R., Platani, C., Spano, G., Monteleone, M., \& Cattivelli, L. (2009). Metabolic profiling and analysis of volatile composition of durum wheat semolina and pasta. Journal of Cereal Science, 49, 301-309.

Bergman, Y. K., Gualberto, D., \& Weber, C. (1994). Development of high-temperaturedried soft wheat pasta supplement with cowpea (Vigna unguiculata L. Walp). Cooking quality, colour and sensory evaluation. Cereal Chemistry, 71, 523-527.

Bjork, I., Liljeberg, H., \& Ostman, E. (2000). Low glycemic index foods. British Journal of Nutrition, 83, 149-155.

Brennan, C. S., Kuri, V., \& Tudorica, C. M. (2003). Inulin-enriched pasta: effects on textural properties and starch degradation. Food Chemistry, 86, 189-193.

Chillo, S., Laverse, J., Falcone, P. M., Protopapa, A., \& Del Nobile, M. A. (2008). Influence of the addition of buckwheat flour and durum wheat bran on spaghetti quality. Journal of Cereal Science, 47, 144-152.

Cleary, L., \& Brennan, C. (2006). The influence of a $(1 \rightarrow 3)(1 \rightarrow 4)-\beta$-D-glucan rich fraction from barley on the physico-chemical properties and in vitro reducing sugars release of durum wheat pasta. International Journal of Food Science and Technology, 41, 910-918.

Cohen, Z., Vonshak, A., \& Richmond, A. (1988). Effect of environmental conditions on fatty acid composition of the red algae Porphyridium cruentum: correlation to growth rate. Journal of Phycology, 24, 328-332.

Crawford, M. (2000). Placental delivery of arachidonic acid and docosahexaenoic acid: implication of the lipid nutrition of preterm infants. American Journal of Clinical Nutrition, 71, 275S-284S.

Cubadda, R. (1994). Nutritional value of pasta - effects of processing conditions. Italian Food Beverage Technology, 3, 27-33.

Donato, M. Vilela, M. H. \& Bandarra, N. M. (2003). Fatty acids sterols and $\alpha$ tocopherol and total carotenoids composition of Diacronema vlkianum. Journal of Food Lipids, 10, 25-34.

Douglass, J. S., \& Mathews, R. H. (1982). Nutrient content of pasta products. Cereal Foods World, 27, 558-561.

Doxastakis, G., Papageorgiou, M., Mandalou, D., Irakli, M., Papalamprou, E., D'Ágostina, A., et al. (2007). Technological properties and non-enzymatic browning of white lupin protein enriched spaghetti. Food Chemistry, 101, 57-64.

Edwards, N. M., Izydorczyk, M. S., Dexter, J. E., \& Biliaderis, C. G. (1993). Cooked pasta texture: comparison of dynamic viscoelastic properties to instrumental assessment of firmness. Cereal Chemistry, 70, 122-126.

Fabregas, J., \& Herrero, C. (1990). Vitamin content of four marine microalgae. Potential use as source of vitamins in nutrition. Journal of Industrial Microbiology, 5, 259-264.

Feillet, P., \& Dexter, J. E. (1996). Quality requirements of durum wheat for semolina milling and pasta production. In J. E. Kruger, R. R. Matsuo, \& J. W. Dick (Eds.), Pasta and noodle technology (pp. 95-131). St. Paul, MN, USA: American Association of Cereal Chemists.

Flynn, K. J., Zapata, M., Garrido, J. L., Opik, H., \& Hipkin, C. R. (1993). Changes in carbon and nitrogen physiology during nitrate nutrition and nitrogen starvation in Isochrysis galbana ammonium. European Journal of Phycology, 28, 47-52.

Fradique, M., Batista, A. P., Nunes, M. C., Gouveia, L., Bandarra, N. M., \& Raymundo, A. (2010). Chlorella vulgaris and Spirulina maxima biomass incorporation in pasta products - part I: preparation and evaluation. Journal of the Science and Food and Agriculture, 90, 1656-1664.

Funk, C. D. (2001). Prostaglandins and leukotrienes: advances in eicosanoid biology. Science, 294, 1871-1875.

Gebauer, S., Harris, W. S., Kris-Etherton, P. M., \& Etherton, T. D. (2004). Dietary n6:n-3 fatty acid ratio and health. In C. C. Akoh, \& O.-M. Lai (Eds.), Healthful lipids (pp. 221-248). Champaign, Illinois, USA: AOCS Press.

Ghosh, P., Patterson, G. W., \& Wikfors, G. H. (1998). Sterols of some marine Prymnesiophyceae. Journal of Phycology, 34, 511-514. 
Ghys, A., Bakkere, E., Hornstra, G., \& Van der Hout, M. (2002). Red blood cell and plasma phospholipid arachidonic and docosahexaenoic acid levels at birth and cognitive development at 4 years of age. Early Human Development, 69, 83-90.

Gibson, R. A., \& Makrides, M. (2001). Long-chain polyunsaturated fatty acids in breast milk: are they essential? Advances in Experimental Medicine and Biology, $501,375-383$.

Gill, I., \& Valivety, R. (1997). Polyunsaturated fatty acids: part 1. Occurrence, biological activities and application. Trends in Biotechnology, 15, 401-409.

Gouveia, L., Batista, A. P., Miranda, A., Empis, J., \& Raymundo, A. (2007). Chlorella vulgaris biomass used as colouring source in traditional butter cookies. Innovative Food Science and Emerging Technologies, 8, 433-436.

Gouveia, L., Batista, A. P., Raymundo, A., \& Bandarra, N. M. (2008). Spirulina maxima and Diacronema vlkianum microalgae in vegetable gelled desserts. Nutrition and Food Science, 38, 492-501.

Gouveia, L., Batista, A. P., Raymundo, A., Sousa, I., \& Empis, J. (2006). Chlorella vulgaris and Haematococcus pluvialis biomass as colouring and antioxidant in food emulsions. European Food Research and Technology, 222, 362-367.

Gouveia, L., Coutinho, C., Mendonça, E., Batista, A. P., Sousa, I., Bandarra, N. M., et al. (2008). Sweet biscuits with Isochrysis galbana microalga biomass as a functional ingredient. Journal of the Science of Food and Agriculture, 88, 891-896.

Guinea, G. V., Rojo, F. J., \& Elices, M. (2004). Brittle failure of dry spaghetti. Engineering Failure Analysis, 11, 705-714.

Horrocks, L. A., \& Yeo, Y. K. (1999). Health benefits of docosahexaenoic acid (DHA). Pharmaceutical Research, 40, 211-225.

Iafelice, G., Caboni, M. F., Cubadda, R., Di Criscio, T., Trivisonno, M. C., \& Marconi, E (2008). Development of functional spaghetti enriched with long-chain omega-3 fatty acids. Cereal Chemistry, 85, 146-151.

ISSFAL. (2004). Recommendations for dietary intake of polyunsaturated fatty acids in healthy adults (pp. 11-12). International Society for the Study of Fatty Acids and Lipids.

Jeffrey, S. W., Brown, M. R., \& Volkman, J. K. (1994). Haptophytes as feedstocks in mariculture. In J. C. Green, \& B. Leadbeater (Eds.), The haptophyte algae (pp. 287) Oxford: Clarendon Press.

Jenkins, D. J., Wolever, T. M., \& Jenkijns, A. L. (1988). Starchy foods and glycemic index. Diabetes Care, 11, 149-159.

Kolanowski, W., \& Laufenberg, G. (2006). Enrichment of food products with polyunsaturated fatty acids by fish oil addition. European Food Research and Technology, 222, 472-477.

Kris-Etherton, P. M., Harris, W. S. H., \& Lawrence, J. A. (2003). Omega-3 fatty acids and cardiovascular disease: new recommendations from the American Heart Association. Arteriosclerosis Thrombosis and Vascular Biology, 23, 151-152.

Lebeau, T., \& Robert, J. M. (2003). Diatom cultivation and biotechnology relevant products: part II. Current and putative products. Applied Microbiology and Biotechnology, 60, 624-632.

Lepage, G., \& Roy, C. C. (1986). Direct transesterification of all classes of lipids in a one-step reaction. Journal of Lipid Research, 27, 114-119.

Liu, C. P., \& Lin, L. P. (2001). Ultrastructural study and lipid formation of Isochrysis sp. CCMP1324. Botanical Bulletin of Academia Sinica, 42, 207-214.

Molina Grima, E., Belarbi, E. H., Acién Fernández, F. G., Robles Medina, A., \& Chisti, Y. (2003). Recovery of microalgal biomass and metabolites: process options and economics. Biotechnology Advances, 20, 491-515.

Nettleton, J. A. (1995). Omega-3 fatty acids and health. New York: Chapman \& Hall.

Pernet, F., Tremblay, R., Demers, E., \& Roussy, M. (2003). Variation of lipid class and fatty acid composition of Chaetoceros muelleri and Isochrysis sp. grown in a semicontinuous system. Aquaculture, 221, 393-406.

Poisson, L., \& Ergan, F. (2001). Docosahexaenoic acid ethyl esters from Isochrysis galbana. Journal of Biotechnology, 91, 75-81.

Ponis, E., Probert, I., Véron, B., Mathieu, M., \& Robert, R. (2006). New microalgae for the Pacific oyster Crassostrea gigas larvae. Aquaculture, 253, 618-627.
Prabhasankar, P., Ganesan, P., Bhaskar, N., Hirose, A., Stephen, N., Gowda, L. R., et al. (2009). Edible Japanese seaweed, wakame (Undaria pinnatifida) as an ingredient in pasta: chemical, functional and structural evaluation. Food Chemistry, 115, 501-508.

Pulz, O., \& Gross, W. (2004). Valuable products from biotechnology of microalgae. Applied Microbiology and Biotechnology, 65, 635-648.

Raymundo, A., Gouveia, L., Batista, A. P., Empis, J., \& Sousa, I. (2005). Fat mimetic capacity of Chlorella vulgaris biomass in oil-in-water food emulsions stabilised by pea protein. Food Research International, 38, 961-965.

Renaud, S. M., Thinh, L. V., Lambrinidis, G., \& Parry, D. L. (2002). Effect of temperature on growth, chemical composition and fatty acid composition of tropical Australian microalgae grown in batch cultures. Aquaculture, 211, 195-214.

Sánchez, S., Martínez, M. E., \& Espinola, F. (2000). Biomass production and biochemical variability of the marine microalga Isochrysis galbana in relation to culture medium. Biochemistry Engineering Journal, 6, 13-18.

Saoudi-Helis, L., Dubacq, J. P., Marty, Y., Samain, J. F., \& Gudin, C. (1994). Influence of growth rate on pigment and lipid composition of the microalga Isochrysis aff. galbana clone T.iso. Journal of Applied Phycology, 6, 315-322.

Shahidi, F., \& Wanasundara, U. N. (1998). Omega-3 fatty acid concentrates: nutritional aspects and production technologies. Trends in Food Science and Technology, 9, 230-240.

Simopolous, A. P. (1999). Essential fatty acids in health and chronic disease. American Journal of Clinical Nutrition, 70, 560S-569S.

Simopoulos, A. P. (2002). The importance of the ratio of omega-6/omega-3 essential fatty acids. Biomedicine and Pharmacotherapy, 56, 365-379.

Trautwein, E. A., Schulz, C., Rieckhoff, D., Kunath-Rau, A., Erbersdobler, H. F., Arjan De Groot, W., et al. (2002). Effect of esterified 4-desmethylsterols and -stanols or 4,4'-dimethylsterols on cholesterol and bile acid metabolism in hamsters. British Journal of Nutrition, 87(3), 227-237.

Tudorica, C. M., Kuri, V., \& Brennan, C. S. (2002). Nutritional and physicochemical characteristics of dietary fiber enriched pasta. Journal of Agricultural and Food Chemistry, 50, 347-356.

Verardo, V., Ferioli, F, Riciputi, Y., Iafelice, G., Marconi, E., \& Caboni, M. F. (2009). Evaluation of lipid oxidation in spaghetti pasta enriched with long chain $n-3$ polyunsaturated fatty acids under different storage conditions. Food Chemistry, $114,472-477$.

Volkman, J. K. (2003). Sterols in microorganisms. Applied Microbiology and Biotechnology, 60, 495-506.

Volkman, J. K., Barrett, S. M., Blackburn, S. I., Mansour, M. P., Sikes, E. L., \& Gelin, F. (1998) Organic Geochemistry, 29, 1163.

Volkman, J. K., Farmer, C. L., \& Barrett, S. M. (1997). Unusual dihydroxysterols as chemotaxonomic markers for microalgae from the order Pavlovales (Haptophyceae). Journal of Phycology, 33, 1016-1023.

Volkman, J. K., Smith, D. J., Eglinton, G., Forsberg, T. E. V., \& Corner, E. D. S. (1981). Sterol and fatty acid composition of four marine haptophycean algae. Journal of the Marine Biological Association of the United Kingdom, 61, 509-527.

Vonshak, A. (1986). Laboratory techniques for the cultivation of microalgae. In A. Richmond (Ed.), Handbook of microalgal mass culture (pp. 117-143). California: CRC Press.

Welch, A. A., Lund, E., Amjano, P., Dorronsoro, M., Brustad, M., \& Kumie, M. (2003) Diet, nutrition and the prevention of chronic diseases. Overvad, World Health Organization. Geneva, Switzerland: World Health Organization. http://www. who.int/hpr/NPH/docs/who fao expert report.pdfS Accessed 07.09.09.

Xu, J. L., Yan, X. J., \& Wang, X. S. (2004). Simultaneous analysis of fatty acid and sterol in marine microalgae. Journal of Marine Science, 28, 19-24.

Yongmanitchai, W., \& Ward, O. P. (1989). Omega-3 fatty acids: alternative sources of production. Process Biochemistry, 24, 117-125. 